\title{
Pyrolysis of Styrene, Acrylate, and Isoprene Polymers in a Vacuum *
}

\author{
S. Straus and S. L. Madorsky
}

\begin{abstract}
Pyrolysis was carried out in a vacuum in the temperature range $250^{\circ}$ to $400^{\circ} \mathrm{C}$. The volatile products were collected and fractionated. The more volatile products were analyzed in the mass spectrometer, whereas the less volatile products were tested for their average molecular weights.

In the styrene group of polymers, poly-alpha-methylstyrene yielded practically 100 percent of monomer, and poly-meta-methylstyrene and poly-alpha-deuterostyrene yielded about 52 and 70 percent, respectively, of monomer or similar products, the other volatiles consisting of dimer, trimer, and some tetramer. Hydrogenated polystyrene yielded volatiles consisting of 6 percent of small molecules and a mixture of products of average molecular weight of 602 .

In the acrylate group of polymers, benzoyl peroxide polymerized polymethyl methacrylate, molecular weight 150,000 , and thermally prepared polymethyl methacrylate, molecular weight 5,100,000, yielded almost 100 percent of monomer. Polymethyl acrylate yielded carbon dioxide, methanol, and a mixture of various fragments, of average molecular weight of 686 .

In the isoprene group of polymers, synthetic polyisoprene, natural rubber (cis-polyisoprene), and gutta hydrocarbon (trans-polyisoprene), yielded isoprene, dipentene, and mixtures of large molecules of average molecular weight of about 600 .
\end{abstract}

\section{Introduction}

In two previous papers $[1,2]^{2}$ a new method for the pyrolysis of polymers has been described. These polymers included polystyrene, polyisobutene, polyisoprene, polybutadiene, GR-S and polyethylene. It was found that in the temperature range of about $300^{\circ}$ to $450^{\circ} \mathrm{C}$ these polymers break up into volatile fragments varying in size from a monomer to products of molecular weight of about 1,000. It was also found that in all cases, except polybutadiene, composition and relative amounts of the volatile products, in the temperature range covered, were independent of temperature or extent of volatilization. In case of polybutadiene, while the nature of the volatile compounds was the same their relative amounts varied.

There appears to be a fundamental difference in the behavior of the various polymers during pyrolysis This difference is in the ratio between the amount of monomer or similar fragments, on the one hand, and that of larger fragments in the volatile products, on the other. For example, in the case of polyethy- lene, the amount of smaller molecules is equal to about 3 weight percent, or 21 mole percent, of the total volatilized part. For polyisobutene this amount is 32 weight percent, or 78 mole percent. Free radicals, once formed, can either split off monomer units or abstract a hydrogen from other chains or possibly its own chain. The less favorable the conditions are in the polymer for the abstraction process (transfer) the higher is the probability of producing monomer. When a break occurs in a polyethylene chain there is a sufficient supply of susceptible hydrogen $[3,4]$ on the same chain or on the other chains in the neighborhood of the break to saturate the free radical ends.

In the case of polyisobutene, saturation of the free radical ends cannot take place as readily as in polyethylene, first, because hydrogen atoms on the chains are less abundant, and second, because of steric hindrance of the methyl groups on the chains. As a result, free radical ends, formed by rupture of bonds during pyrolysis, serve as starting points for monomer formatioa:

and
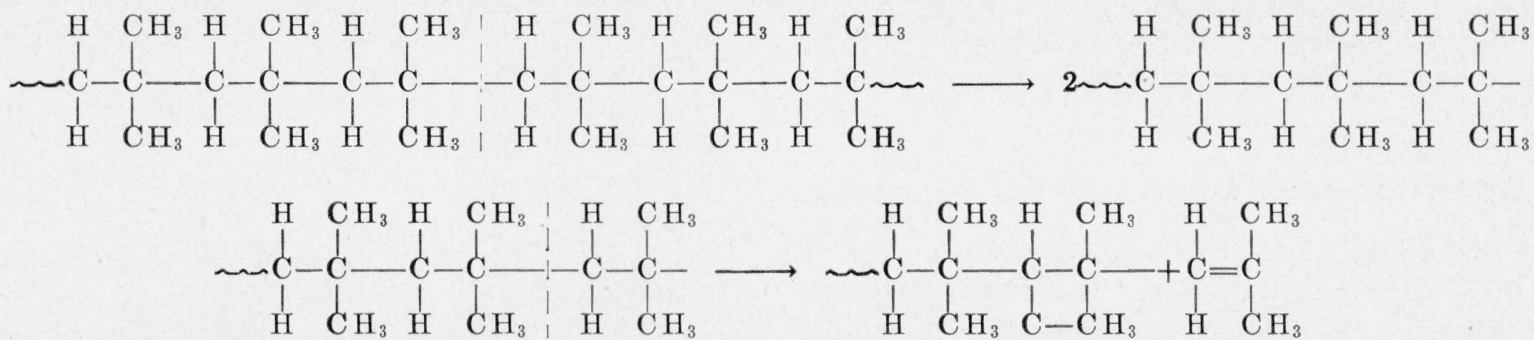

* This work was performed as a part of the research project sponsored by the Reconstruction Finance Corporation, Office of Synthetic Rubber, in connection with the Government Synthetic Rubber Program.

This paper was presented at the 122d meeting of the American Chemical Society in Atlantic City, N. J., Sept. 14 to 19, 1952.

Figures in brackets indicate the literature references at the end of this paper. 
This process will continue in the manner of a zip reaction until the chain is consumed, or until the free radical becomes saturated.

Another fundamental difference between polyethylene and polyisobutene lies in their relative $\mathrm{C}-\mathrm{C}$ bond strength. In polyethylene all the bonds, except those at the ends, are normal paraffin bonds, whereas in polyisobutene the bonds are weaker because they are adjacent to tertiary carbons. The same is true of polystyrene, where every bond in the chain is adjacent to a secondary carbon. An additional weakness in the polystyrene chain molecule is caused by the double bonds of the benzene ring. These double bonds tend to weaken the $\mathrm{C}-\mathrm{C}$ bond in the beta position, thus

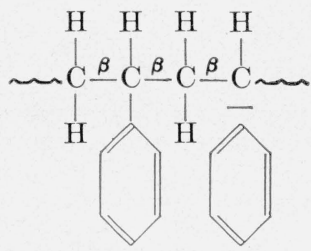

This is also true of polybutadiene<smiles>CC=CCCCC</smiles>

and polyisoprene.

In the present work a study was made of the effect of variations in the side groups of a polymer on thermal stability and nature and relative amounts of the volatile fragments. Three types of polymers were selected for this purpose:

1. The polystyrene type, including poly-metamethylstyrene, poly-alpha-deuterostyrene, poly-alpha-methylstyrene, and hydrogenated polystyrene.

2 . The acrylate type, including benzoyl peroxide polymerized polymethyl methacrylate $\mathrm{A}$, molecular weight 150,000 , thermally prepared polymethyl methacrylate B, molecular weight $5,100,000$, and polymethyl acrylate.

3 . The isoprene type, including synthetic polyisoprene, natural rubber (cis-polyisoprene), and gutta hydrocarbon (trans-polyisoprene).

Pyrolysis of polyisoprene has been described in a previous paper [2]. The investigation has now been extended to include the isoprene-dipentene ratio in the volatile products. Pyrolysis of some of the above polymers has been investigated recently by others $[5,6,7]$.

\section{Apparatus and Experimental Procedure}

The molecular still used for the pyrolysis of polymers in this investigation was the same as was used in the previous work $[1,2]$. It consists of a Dewarlike Pyrex-glass apparatus made of two concentric parts jointed by ground waxed flanges. All the polymers were used in the form of a 2-percent solution in benzene. The solution was spread in a platinum tray, and most of the solvent was evaporated in a vacuum of about 10 to $15 \mathrm{~mm} \mathrm{Hg}$ at room temperature. The tray was then preheated in a vacuum of about $10^{-3}$ to $10^{-4} \mathrm{~mm} \mathrm{Hg}$ at $100^{\circ}$ to $130^{\circ} \mathrm{C}$ to a constant weight. This usually required about $2 \mathrm{hr}$. The dry sample weight was from 20 to $60 \mathrm{mg}$. It was found that when the sample was larger, for the size of the tray used in this work, spattering resulted during pyrolysis.

The tray was placed on top of an electric heater in the pyrolysis apparatus evacuated to about $10^{-6} \mathrm{~mm}$ $\mathrm{Hg}$. The sample was heated up to the maximum temperature of a given experiment during a period of $45 \mathrm{~min}$, and this temperature was then maintained for $30 \mathrm{~min}$. Precautions were taken against desorption of gases from the wall of the apparatus in the neighborhood of the electric heater, by first flaming gently the outside of the Dewar-like apparatus and then raising a water thermostat against the apparatus so that the level of the water reached above the level of the enclosed heater. Temperature of pyrolysis was read by means of a Pt-PtRh thermocouple spot-welded to the tray at its center

The method employed in this investigation is designated as pyrolytic fractionation [1]. The volatile products are fractionated for two reasons: (1) to be able to differentiate between monomer or monomersize molecules, on the one hand, and the larger fragments in the volatiles, on the other, and (2) to facilitate mass-spectrometric analysis of the more volatile products. The following fractions were collected:

I. Hard glass-like residue in the tray.-This fraction was weighed and its solubility in ordinary organic solvents determined. Nothing further was done with this fraction. It is planned to study in the near future the average molecular weight of the residues as a function of temperature and extent of degradation. For this purpose larger samples will be pyrolyzed in a larger apparatus.

II. Wax-like fraction, volatile at the temperature of pyrolysis, but not at room temperature. - This fraction was weighed and analyzed for average molecular weight by Rast's microcryoscopic method in cyclohexane, benzene, or camphor. Rast's method [8] was checked by the present authors on a number of pure compounds. The results of this check, with $\mathrm{C}_{6} \mathrm{H}_{12}$ and $\mathrm{C}_{6} \mathrm{H}_{6}$ as solvents, were reported previously [2]. In checking this method the values used for $\vec{F}$, the molecular freezing-point lowering, were $20.0^{\circ}$ and $5.12^{\circ} \mathrm{C}$ for $\mathrm{C}_{6} \mathrm{H}_{12}$ and $\mathrm{C}_{6} \mathrm{H}_{6}$, respectively. In the case of camphor as solvent, a check was made with pure nonacosane, molecular weight 409 , as solute. Using the value of $39.7^{\circ} \mathrm{C}$ for $F$, the results of two sets of determinations were

\begin{tabular}{|c|c|c|}
\hline \multicolumn{2}{|c|}{1} & 2 \\
\hline & $\begin{array}{l}420 \\
386 \\
415\end{array}$ & $\begin{array}{l}409 \\
409 \\
400\end{array}$ \\
\hline Average_. & 407 & 406 \\
\hline
\end{tabular}


The molecular weight of fraction II from polymethyl acrylate was determined by a method involving rates of isothermal distillation in a vacuum, developed by G. Gee [9] and modified by D. J. Brawley and S. G. Weissberg [10], using toluene as solvent

III. Liquid fraction volatile at room temperature, but not at the temperature of liquid nitrogen.-This fraction was weighed and was then analyzed in the mass spectrometer. It consisted, in the case of some polymers, of the monomer only; in the case of other polymers, also of dimer, trimer, and fragments of monomer, dimer and trimer. To facilitate further the mass-spectrometer analysis, fraction III in some cases was again fractionated into a lighter fraction IIIA, containing mostly the monomer-size fragments, and a heavier fraction IIIB, containing mostly the dimer-size fragments. Separation into IIIA and IIIB was carried out at $-80^{\circ} \mathrm{C}$ by a method described in a previous publication [2]. Composition of IIIA and IIIB was determined by mass-spectrometer analysis. In some cases where fraction III or IIIA was large, or where it was suspected to contain compounds larger than the monomer, the sample was expanded into a larger volume by a method described previously [1]. This step was found useful, because the presence of heavier molecules is masked in massspectrometer analysis by the lighter molecules when the total pressure is too high.

IV. Gaseous fraction, volatile at the temperature of liquid nitrogen.- This fraction in all cases was of the order of about 0.1 percent of the total volatilized part and consisted of traces of $\mathrm{CH}_{4}, \mathrm{CO}_{2}$, and $\mathrm{CO}$, as determined by mass-spectrometer analysis. The weight of this fraction was calculated from its volume, pressure, and composition.

\section{Pyrolysis of Styrene Polymers}

\subsection{Poly-meta-methylstyrene}

A pure grade of poly-meta-methylstyrene, containing some para-methylstyrene as part of its struc-

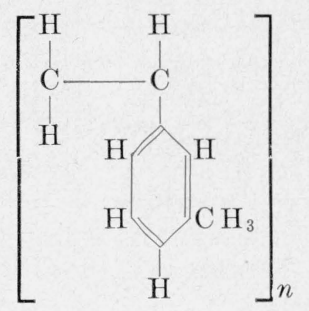

ture, was used. It was prepared by the Dow Chemical Co. by low-temperature polymerization and had an average molecular weight of 450,000 , as determined by the light-scattering method. ${ }^{3}$ Results of seven experiments ranging from $309^{\circ}$ to $399^{\circ} \mathrm{C}$ are shown in table 1 . The amount of fraction III in weight percent of the volatilized part remained

3 Work on molecular-weight determinations by the light-scattering method was carried out by M. Wales and L. C. Williams of the Polymer Structure Section of the National Bureau of Standards.
TABLE 1. Pyrolitic fractionation of styrene polymers

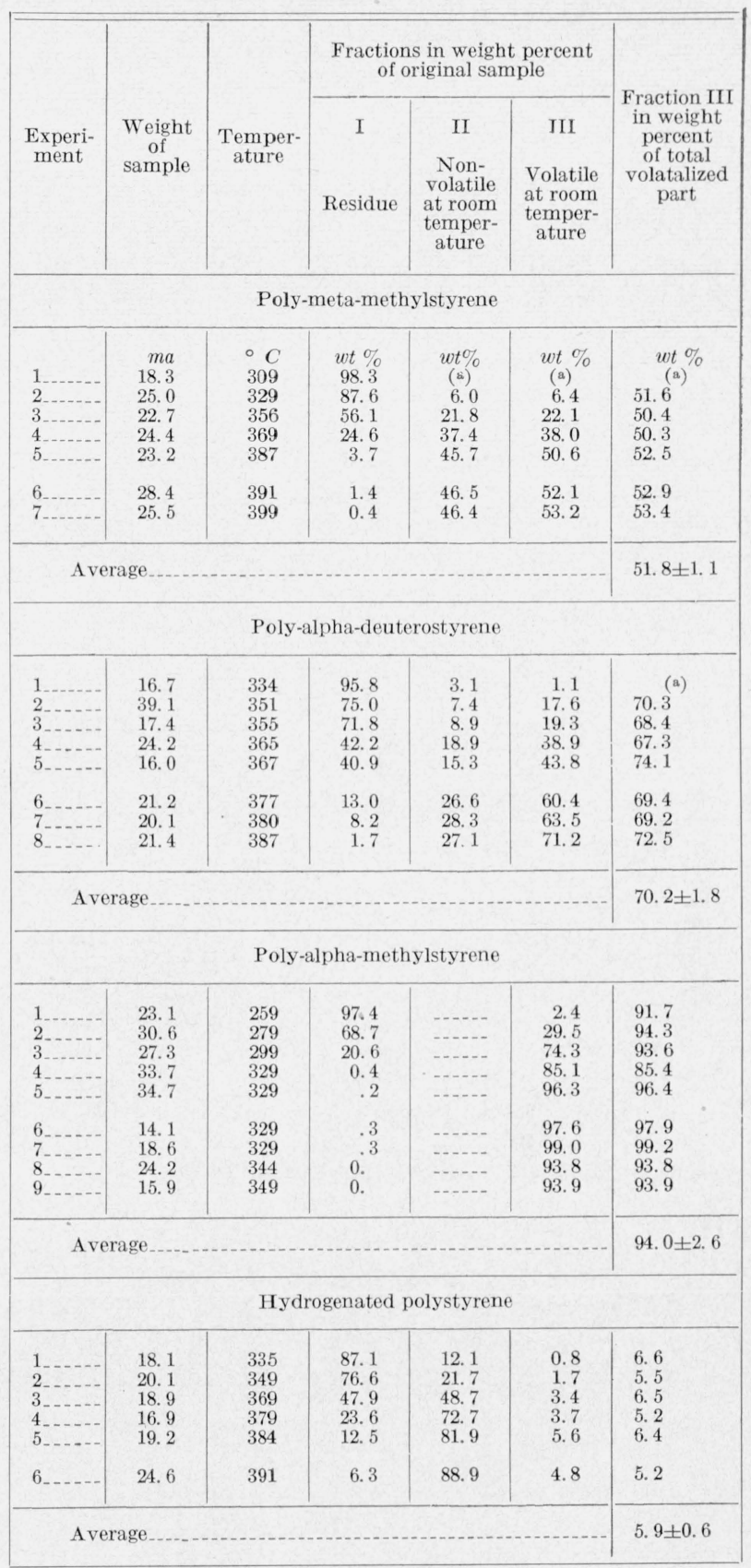

a Too small to be accurately determined.

almost constant throughout the temperature range Fraction III was analyzed, without further fractionation, in the mass spectrometer. Results of four analyses are shown in table 2 . In experiment 7 , fraction III was expanded into a $700-\mathrm{ml}$ volume before it was analyzed. All four analyses gave similar results.

Fraction II was tested for average molecular weight by the microcryoscopic method in $\mathrm{C}_{6} \mathrm{H}_{12}$ solution. The average of three determinations was 
TABLE 2. Mass-spectrometer analysis of fraction III obtained in the pyrolysis of poly-meta-methylstyrene

\begin{tabular}{|c|c|c|c|c|c|c|}
\hline \multirow{2}{*}{ Component } & \multicolumn{4}{|c|}{$\begin{array}{c}\text { Analysis of fraction III in } \\
\text { experiments- }\end{array}$} & \multirow{2}{*}{$\begin{array}{l}\text { Average } \\
\text { of exper- } \\
\text { iments } \\
2,3,5,7\end{array}$} & \multirow{2}{*}{$\begin{array}{l}\text { Average } \\
\text { for total } \\
\text { volatil- } \\
\text { ized } \\
\text { part }\end{array}$} \\
\hline & 2 & 3 & 5 & 7 & & \\
\hline $\begin{array}{l}\text { Xylene } \\
\text { Meta-methylstyrene }\end{array}$ & $\begin{array}{l}\text { Mole \% } \\
\quad 16.3 \\
\quad 83.7\end{array}$ & $\begin{array}{c}\text { Mole \% } \\
20.4 \\
79.6\end{array}$ & $\begin{array}{r}\text { Mole \% } \\
8.1 \\
91.9\end{array}$ & $\begin{array}{r}\text { Mole \% } \\
16.8 \\
83.2\end{array}$ & $\begin{array}{c}\text { Mole \% } \\
15.5 \\
84.5\end{array}$ & $\begin{array}{r}W t \% \\
7.3 \\
44.5\end{array}$ \\
\hline Total & 100.0 & 100.0 & 100.0 & 100.0 & 100.0 & 51.8 \\
\hline
\end{tabular}

355 , as shown in table 3 . The gaseous fractions IV from experiments $2,3,5$, and 7 were analyzed in the mass spectrometer. There was no $\mathrm{CH}_{4}$ present, but only traces of $\mathrm{CO}$ and $\mathrm{CO}_{2}$. The $\mathrm{CO}$ might have come from oxygen as an impurity in the polymer, and the $\mathrm{CO}_{2}$ was the background in the mass spectrometer. Fraction I was soluble in cold benzene.

TABLE 3. Molecular weights of fractions II obtained in the pyrolysis of polymers

\begin{tabular}{|c|c|c|}
\hline$\therefore \quad$ Polymer & Solvent & $\begin{array}{c}\text { Average } \\
\text { molecular } \\
\text { weight }\end{array}$ \\
\hline Polyethylene a. & Camphor & 692 \\
\hline Polyisobutene & Cyclohexane...... & 543 \\
\hline Hydrogenated polystyrene & _. do & 602 \\
\hline Polystyrene & .... do & 264 \\
\hline Poly-meta-methylstyrene & -.... do & 355 \\
\hline Poly-alpha-deuterostyrene.. & do & 271 \\
\hline Polymethyl acrylate $\ldots . . .$. & Toluene $b_{-}$ & 633 \\
\hline Polymethyl methacrylate A & Camphor_..... & 686 \\
\hline Polyisoprene & Cyclohexane ...... & 577 \\
\hline trans-Polyisoprene.. & Benzene............ & 554 \\
\hline cis-Polyisoprene... & Camphor ......... & 616 \\
\hline Polybutadiene_. & Cyclohexane....... & 739 \\
\hline
\end{tabular}

- Values for polyethylene, polyisobutene, polystyrene, polyisoprene, and polybutadiene were taken from previous publications [1, 2].

$\mathrm{b}$ The isot?ermal distillation method was used for polymethyl-acrylate.

\subsection{Poly-alpha-deuterostyrene}

The alpha-deuterostyrene monomer<smiles>C=Cc1ccccc1</smiles>

was prepared ${ }^{4}$ by reacting lithium-aluminum deuteride with acetophenone. The polymer was prepared thermally at $70^{\circ} \mathrm{C}$. It had a molecular weight of 1,260,000 as determined by light scattering. Pyrolysis was carried out in the temperature range $334^{\circ}$ to $387^{\circ} \mathrm{C}$. The results are shown in table 1 . The average value of fraction III is $70.2 \pm 1.8$ weight percent of the total volatilized part, as compared with 42 for polystyrene [1] or 51.8 for poly-metamethylstyrene.

Results of mass-spectrometer analysis of fraction

4 This polymer, as well as polymethyl methacrylate B and polymethyl acrylatel were prepared by L. A. Wall of the Polymer Structure Section of the Nationa, Bureau of Standards.
III, from experiments 2,5 , and 7 , are shown in table 4. This fraction consisted mainly of the monomer and small amounts of styrene and alphamethylstyrene. In the case of fraction III from two experiments, the tubes containing them were opened in air and loss of weight was plotted as a function of time, in the same manner as described in a previous paper on pyrolysis of polystyrene [1]. The resulting curves indicated the absence of fragments heavier than the monomer. In view of this, separation of fraction III into IIIA and IIIB was not undertaken.

TABLE 4. Mass-spectrometer analysis of fraction III obtained in the pyrolysis of poly-alpha-deuterostyrene

\begin{tabular}{|c|c|c|c|c|c|}
\hline \multirow{2}{*}{ Component } & \multicolumn{3}{|c|}{$\begin{array}{c}\text { Analysis of fraction III in } \\
\text { experiments- }\end{array}$} & \multirow{2}{*}{$\begin{array}{l}\text { Average } \\
\text { of ex- } \\
\text { periments } \\
2,5,7\end{array}$} & \multirow{2}{*}{$\begin{array}{l}\text { A verage } \\
\text { for total } \\
\text { volatil- } \\
\text { ized } \\
\text { part }\end{array}$} \\
\hline & 2 & 5 & 7 & & \\
\hline \multirow{4}{*}{$\begin{array}{l}\text { Styrene } \\
\text { Alpha-deuterosty- } \\
\text { rene. } \\
\text { Alpha-methylstyrene } \\
\text { Total }\end{array}$} & $\begin{array}{c}\text { Mole } \% \\
2.5\end{array}$ & $\begin{array}{c}\text { Mole \% } \\
1.8\end{array}$ & $\begin{array}{c}\text { Mole } \% \\
2.3\end{array}$ & $\begin{array}{c}\text { Mole } \% \\
2.2\end{array}$ & $\begin{array}{c}w t \% \\
1.5\end{array}$ \\
\hline & 96.9 & 96.6 & 97,4 & 97.0 & 68.1 \\
\hline & 0.6 & 1. 6 & 0.3 & 0.8 & 0.6 \\
\hline & 100.0 & 100.0 & 100.0 & 100.0 & 70.2 \\
\hline
\end{tabular}

The wax-like fraction II from experiments 4, 6, and 8 was found to have an average molecular weight of 271, as shown in table 3 . The gaseous fraction IV from experiments 3,4 , and 5 was analyzed in the mass spectrometer. Only traces of air, CO, and $\mathrm{CO}_{2}$ were found. The residue, fraction I, was soluble in cold benzene.

\subsection{Poly-alpha-methylstyrene}

Poly-alpha-methylstyrene,

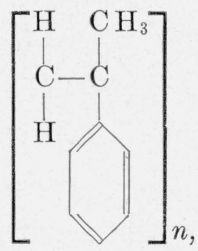

in the form of flakes, was obtained from the Dow Chemical Co. It was prepared by low-temperature polymerization and had a molecular weight of 350,000 as determined by light scattering. Results of nine experiments, in the temperature range $259^{\circ}$ to $349^{\circ} \mathrm{C}$, are given in table 1 . Fraction III represents, on the average, $94.0 \pm 2.6$ percent of the total volatilized part. Mass-spectrometer analysis of this fraction showed the presence of only the monomer. By evaporating fraction III from small tubes in air, it was found that the dimer was absent. The residue was soluble in cold benzene.

There was no indication of a fraction II on the condenser of the pyrolysis apparatus. Because the gaseous fraction IV is less than 0.1 percent of the volatiles, it can be assumed that poly-alpha-methylstyrene, on pyrolysis, yields almost 100 percent of monomer, although the collection of the monomer was incomplete in the experiments shown in table 1. 
Jellinek [6] heated poly-alpha-methylstyrene, of about 70,000 molecular weight, in a vacuum in order to determine the rate of degradation. He used a temperature range of $280^{\circ}$ to $363^{\circ} \mathrm{C}$ and reports that the rate of production of monomer was very fast, but he does not indicate whether fragments other than monomer were formed.

\subsection{Hydrogenated Polystyrene}

The hydrogenated polystyrene<smiles>CCCCCCC</smiles>

was obtained from the Federal Telecommunications Laboratory in the form of a very fine powder. It had a molecular weight of 82,000 , as determined by light scattering. This polymer is very soluble in benzene. Results of six pyrolysis experiments in the temperature range $335^{\circ}$ to $391^{\circ} \mathrm{C}$ are shown in table 1 . Fraction III is very small and, on the average, amounts to $5.9 \pm 0.6$ percent of the total volatilized part. In this respect it resembles polyethylene, where fraction III is 3.4 percent [2]. A quantitative analysis of fraction III could not be obtained in the mass spectrometer because of lack of mass spectra of some of the components. However, mass-spectrometer analysis of fraction III from experiments 4 , 5, and 6 indicated the presence of the following compounds in the order of abundance as given: Cyclohexene, cyclohexane, methyl cyclohexene, methyl cyclohexane, vinyl cyclohexene, vinyl cyclohexane, and ethyl cyclohexane.

Fraction II from experiments 4, 5, and 6 was found to have, on the average, a molecular weight of 602 , as shown in table 3 . Fraction IV was very small, and on mass-spectrometer analysis was found to contain a trace of air and $\mathrm{CO}_{2}$, but no $\mathrm{CH}_{4}$ or $\mathrm{H}_{2}$. The residue was soluble in cold benzene.

\section{Pyrolysis of Acrylate Polymers}

\subsection{Polymethyl Methacrylate A}

This polymer was a benzoyl peroxide polymerized polymethyl methacrylate, analyzing 0.6 percent of benzoyl peroxide and having a molecular weight of 150,000 , as determined by the light-scattering method.<smiles>CCCCC(=O)OCC</smiles>

Results of pyrolysis experiments in the temperature range $140^{\circ}$ to $318^{\circ} \mathrm{C}$ are shown in table 5 . On the average, fraction III represented about 96 percent and fraction II about 4 percent of the total volatilized part. Fraction III consisted of monomer only. Fraction II was collected and tested for average molecular weight. The results showed a molecular weight of 686 (see table 3). Fraction IV was less than 0.1 percent of the volatiles. Mass-spectrometer analysis showed it to consist of $\mathrm{CO}$ and $\mathrm{CO}_{2}$. The residue was soluble in benzene.

TABLE 5. Pyrolytic fractionation of acrylate polymers

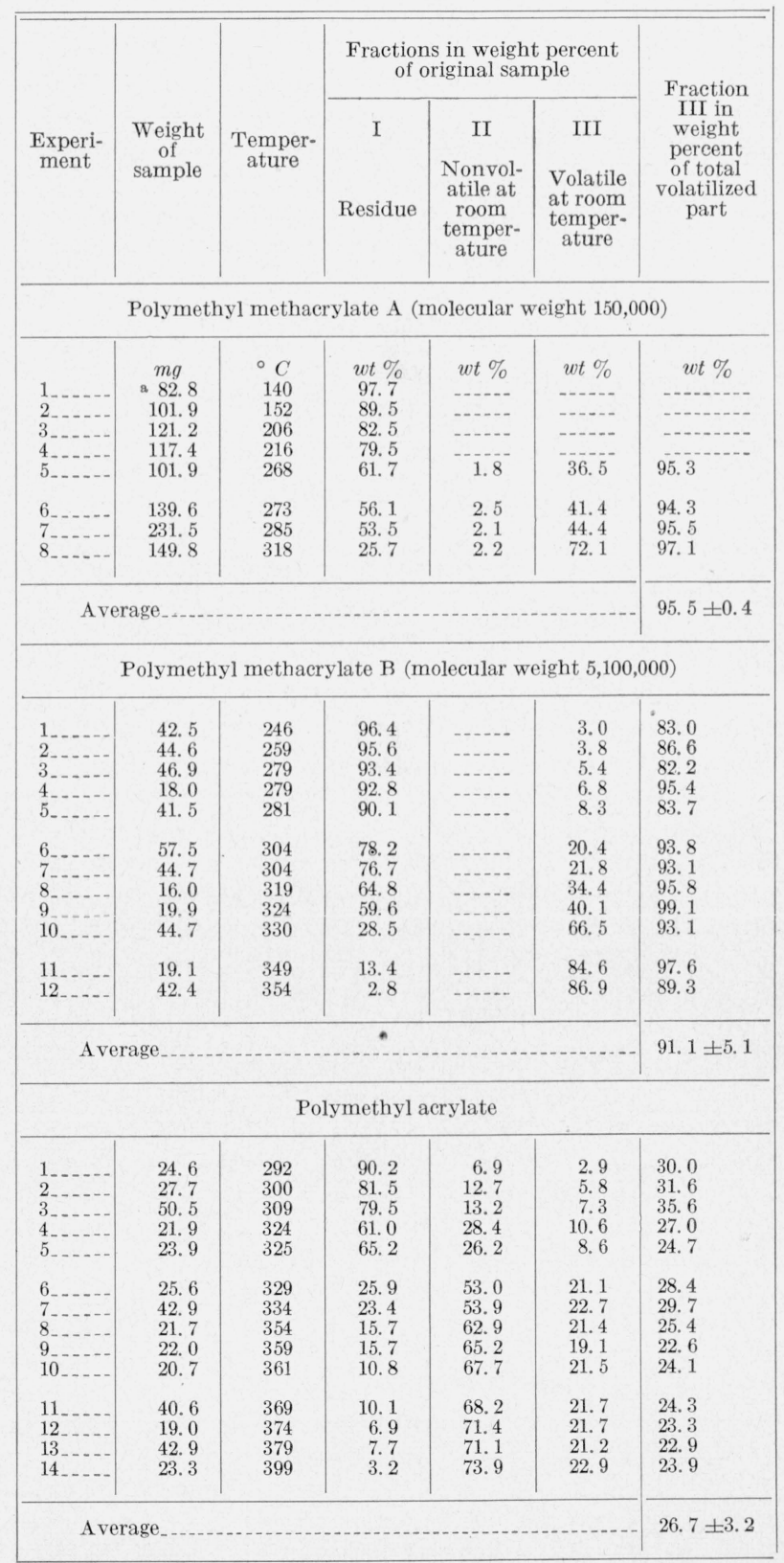

a In this series of experiments a larger pyrolysis apparatus and a larger tray were used than used in the other experiments. 


\subsection{Polymethyl Methacrylate B}

This polymer was prepared by polymerizing the monomer, without the use of a catalyst, at $25^{\circ} \mathrm{C}$, precipitating, and then washing the precipitate several times with methanol. The methanol was removed by evacuation at $60^{\circ} \mathrm{C}$ for $48 \mathrm{hr}$. The molecular weight, as determined by light scattering, was $5,100,000$. Results of experiments in the temperature range $246^{\circ}$ to $354^{\circ} \mathrm{C}$ are shown in table 5.

Fraction III is on the average $91.1 \pm 5.1$ percent of the total volatilized part. Analysis of this fraction from experiments $1,2,3,6$, and 10 showed it to consist entirely of the monomer. Here, as in the case of poly-alpha-methylstyrene, there was no wax-like deposit on the condenser of the pyrolysis apparatus to indicate the presence of a wax-like fraction II. Therefore, the same assumption can be made here that this polymer yields on pyrolysis about 100 percent of monomer, although the collection, as shown in table 5, was not complete.

\subsection{Polymethyl Acrylate}

The polymethyl acrylate<smiles>COC(=O)C1CCCC1</smiles>

was prepared by polymerizing the monomer in benzene solution at $70^{\circ} \mathrm{C}$, using 0.1 mole percent of benzoyl peroxide as catalyst. The polymer was precipitated, then washed several times, with methanol, and dried to a constant weight. Results of 14 pyrolysis experiments, in the temperature range $292^{\circ}$ to $399^{\circ} \mathrm{C}$, are shown in table 5. Fraction III, on the average amounts to $26.7 \pm 3.2$ percent of the volatilized part. It was found by preliminary analysis of this fraction in the mass spectrometer that it contained a considerable amount of $\mathrm{CO}_{2}$, which interfered with the analysis of the other constituents. Fraction III was, therefore, separated into fraction IIIA, which contained most of the $\mathrm{CO}_{2}$, and IIIB, which contained the less volatile constituents. This separation was carried out at $-80^{\circ} \mathrm{C}$. On the average, IIIA amounted to 5.5 percent and IIIB to 21.2 percent of the total volatized part. Mass-spectrometer analyses are shown in table 6 . Fraction IIIA contained mostly $\mathrm{CO}_{2}$, but also small amounts of ethanol, ethane, and ethylene, while IIIB contained mostly ethanol, mixed with small amounts of $\mathrm{CO}_{2}$, methyl acrylate, methyl methacrylate, and some oxygenated $\mathrm{C}_{4}$ to $\mathrm{C}_{6}$ compounds. It is rather surprising that, instead of the monomer, as in polymethyl methacrylate, fraction III consisted mainly of $\mathrm{CO}_{2}$ and $\mathrm{CH}_{3} \mathrm{OH}$.

The wax-like fraction II was tested for molecular weight by the isothermal distillation method. The
TABLE 6. Mass-spectrometer analysis of fractions IIIA and $I I I B$ obtained in the pyrolysis of polymethyl acrylate

\begin{tabular}{|c|c|c|c|c|c|c|c|c|}
\hline \multirow{2}{*}{ Component } & \multicolumn{6}{|c|}{$\begin{array}{l}\text { Analysis of fraction IIIA } \\
\text { in experiments- }\end{array}$} & \multirow{2}{*}{$\begin{array}{c}\text { Aver- } \\
\text { age of } \\
\text { experi- } \\
\text { ments } \\
1,7, \\
10,13\end{array}$} & \multirow{2}{*}{$\begin{array}{l}\text { Aver- } \\
\text { age for } \\
\text { total } \\
\text { volatil- } \\
\text { ized } \\
\text { part }\end{array}$} \\
\hline & 1 & \multicolumn{2}{|c|}{7} & \multicolumn{2}{|c|}{10} & 13 & & \\
\hline $\begin{array}{l}\text { Ethylene... } \\
\text { Ethane } \\
\mathrm{CH}_{3} \mathrm{OH}_{2} \\
\mathrm{CO}_{2}\end{array}$ & $\begin{array}{r}\text { Mole \% } \\
3.7 \\
96.3\end{array}$ & \multicolumn{2}{|c|}{$\begin{array}{c}\text { Mole \% } \\
0.7 \\
99.3\end{array}$} & \multicolumn{2}{|c|}{$\begin{array}{r}\text { Mole \% } \\
0.5 \\
99.5\end{array}$} & $\begin{array}{r}\text { Mole \% } \\
1.5 \\
0.5 \\
98.0\end{array}$ & $\begin{array}{r}\text { Mole \% } \\
0.6 \\
\text { Trace } \\
1.1 \\
98.3\end{array}$ & $\begin{array}{r}W t \% \\
\text { Trace } \\
\text { Do. } \\
0.1 \\
5.4\end{array}$ \\
\hline \multirow[t]{3}{*}{ Total_...- } & 100.0 & \multicolumn{2}{|c|}{100.0} & \multicolumn{2}{|c|}{100.0} & 100.0 & 100.0 & 5.5 \\
\hline & \multicolumn{6}{|c|}{$\begin{array}{l}\text { Analysis of fraction IIIB } \\
\text { in experiments- }\end{array}$} & \multirow{2}{*}{$\begin{array}{c}\text { Aver- } \\
\text { age of } \\
\text { experi- } \\
\text { ments } \\
1,3,5 \\
10,13\end{array}$} & \multirow[b]{3}{*}{$\begin{array}{r}14.5 \\
2.0\end{array}$} \\
\hline & 1 & 3 & 5 & & 10 & 13 & & \\
\hline \multirow{5}{*}{$\begin{array}{l}\mathrm{CH}_{3} \mathrm{OH} \\
\mathrm{CO}_{2} \\
\text { Methyl acry- } \\
\text { late } \\
\text { Methyl meth- } \\
\text { acrylate } \\
\text { Oxygenated } \\
\text { compounds } \\
\mathrm{C}_{4} \text { to } \mathrm{C}_{6}\end{array}$} & \multirow{4}{*}{$\begin{array}{c}88.3 \\
1.2 \\
0.5\end{array}$} & $\begin{array}{l}77.9 \\
16.7\end{array}$ & \multicolumn{2}{|c|}{$\begin{array}{r}84.5 \\
5.1\end{array}$} & $\begin{array}{r}85.4 \\
6.9\end{array}$ & \multirow[t]{2}{*}{$\begin{array}{l}77.7 \\
12.4\end{array}$} & $\begin{array}{r}82.6 \\
8.3\end{array}$ & \\
\hline & & \multirow[b]{2}{*}{$\cdots$} & \multirow{2}{*}{\multicolumn{2}{|c|}{3.9}} & & & & 2.0 \\
\hline & & & & & 2. 3 & & 1. 5 & 0.7 \\
\hline & & $\cdots$ & \multicolumn{2}{|c|}{0.4} & 0.3 & --- & 0.2 & 0.1 \\
\hline & 10.0 & 5.4 & & 1 & 5.1 & 9.9 & 7.4 & 3.9 \\
\hline Total_..- & 100.0 & 100.0 & 100 & & 100.0 & 100.0 & 100.0 & 21.2 \\
\hline
\end{tabular}

average of four tests, as shown in table 3, was 633 . The residue was soluble in cold benzene. The gaseous fraction IV consisted of small amounts of $\mathrm{CO}, \mathrm{CO}_{2}$, and $\mathrm{CH}_{4}$.

\section{Pyrolysis of Isoprene Polymers}

\subsection{Synthetic Polyisoprene}

Pyrolysis of polyisoprene<smiles>C/C=C\C</smiles>

was carried out previously by the present authors [2], but the monomer-dimer ratio in fraction III was not thoroughly investigated at that time. This ratio has now been studied in more detail. The same material was used as in the previous work. Results of 11 pyrolysis experiments are shown in table 7 . The relative amount of fraction III in the volatiles is greater in the early stages of degradation, the same as was found previously, and the average amount in experiments where volatilization was about 68 percent or more is $12.2 \pm 0.6$ percent of the total pyrolyzed part, as compared with $11.3 \pm 0.4$ percent found previously.

It has been known for a long time that isoprene and dipentene are some of the volatile products of thermal degradation of rubber. Dipentene is a dimer of isoprene and could form when a dimer splits off the end of a chain: 


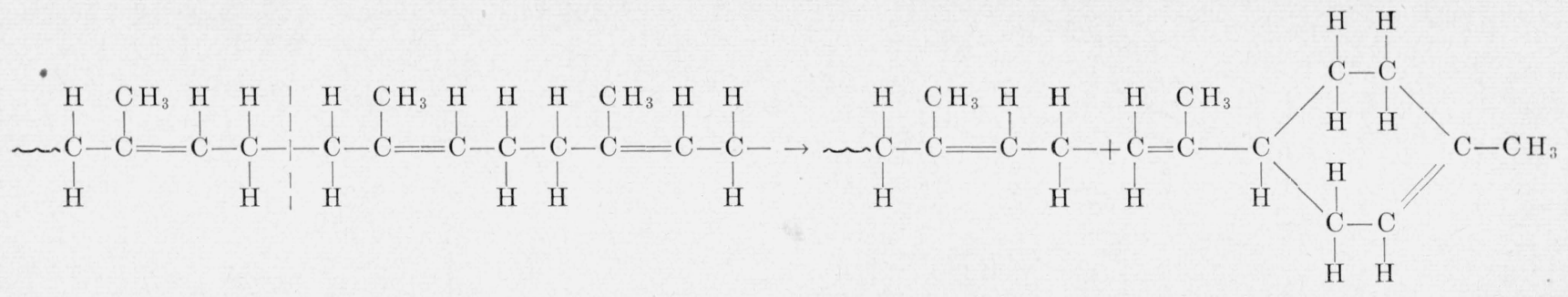

dipentene

Fraction III was separated into IIIA and IIIB at $-80^{\circ} \mathrm{C}$. It was found necessary to extend the time of collecting the lighter fraction IIIA, at the temperature of liquid nitrogen, from a few minutes, as was done in other cases, to $30 \mathrm{~min}$, in order to get a complete separation. Both fractions were analyzed in the mass spectrometer. The results of analysis of fraction IIIA are shown in table 8 . Fraction IIIB consisted mainly of dipentene, mixed

TABLE 7. Pyrolytic fractionation of isoprene polymers

\begin{tabular}{|c|c|c|c|c|c|c|}
\hline \multirow[b]{2}{*}{$\begin{array}{l}\text { Experi- } \\
\text { ment }\end{array}$} & \multirow[b]{2}{*}{$\begin{array}{l}\text { Weight } \\
\text { of } \\
\text { sample }\end{array}$} & \multirow[b]{2}{*}{$\begin{array}{l}\text { Temper- } \\
\text { ature }\end{array}$} & \multicolumn{3}{|c|}{$\begin{array}{l}\text { Fractions in weight percent } \\
\text { of original sample }\end{array}$} & \multirow{2}{*}{$\begin{array}{c}\text { Fraction } \\
\text { III in } \\
\text { weight } \\
\text { percent } \\
\text { of total } \\
\text { volatilized } \\
\text { part }\end{array}$} \\
\hline & & & $\begin{array}{c}\text { I } \\
\text { Residue }\end{array}$ & $\begin{array}{c}\text { II } \\
\text { Nonvol- } \\
\text { atile at } \\
\text { room } \\
\text { temper- } \\
\text { ature }\end{array}$ & $\begin{array}{l}\text { III } \\
\text { Volatile } \\
\text { at room } \\
\text { temper- } \\
\text { ature }\end{array}$ & \\
\hline \multicolumn{7}{|c|}{ Synthetic polyisoprene } \\
\hline $\begin{array}{l}1 \ldots \\
2 \ldots \\
3 \ldots \\
4 \ldots \\
5\end{array}$ & $\begin{array}{c}m g \\
59.1 \\
50.2 \\
55.5 \\
46.6 \\
54.5\end{array}$ & $\begin{array}{l}{ }^{\circ} C \\
309 \\
314 \\
317 \\
320 \\
333\end{array}$ & $\begin{array}{l}w t \% \\
78.7 \\
73.2 \\
68.6 \\
55.7 \\
31.8\end{array}$ & $\begin{array}{l}w t \% \\
17.4 \\
22.4 \\
25.9 \\
37.6 \\
59.4\end{array}$ & $\begin{array}{l}w t \% \\
3.9 \\
4.4 \\
5.5 \\
6.7 \\
8.8\end{array}$ & $\begin{array}{l}w t \% \\
18.1 \\
16.8 \\
17.6 \\
16.1 \\
13.0\end{array}$ \\
\hline $\begin{array}{l}6 \\
7 \\
8 \\
9 \\
10\end{array}$ & $\begin{array}{l}28.1 \\
50.6 \\
48.8 \\
32.5 \\
42.8\end{array}$ & $\begin{array}{l}336 \\
340 \\
351 \\
367 \\
369\end{array}$ & $\begin{array}{r}25.0 \\
23.4 \\
13.4 \\
6.4 \\
4.3\end{array}$ & $\begin{array}{l}65.8 \\
66.3 \\
77.1 \\
81.7 \\
84.6\end{array}$ & $\begin{array}{r}9.2 \\
10.3 \\
9.5 \\
11.9 \\
11.1\end{array}$ & $\begin{array}{l}12.2 \\
12.9 \\
11.0 \\
12.7 \\
11.9\end{array}$ \\
\hline $11 \ldots$ & 47.0 & 369 & 4. 9 & 84.1 & 11.0 & 11.6 \\
\hline \multicolumn{6}{|c|}{ A verage_. } & a $12.2 \pm 0.6$ \\
\hline \multicolumn{7}{|c|}{ Natural rubber (cis-polyisoprene) } \\
\hline $\begin{array}{l}1 \ldots \\
2 \ldots \\
3 \\
4 \ldots \\
5 \ldots\end{array}$ & $\begin{array}{l}40.8 \\
47.8 \\
30.4 \\
59.9 \\
44.7\end{array}$ & $\begin{array}{l}287 \\
302 \\
309 \\
311 \\
313\end{array}$ & $\begin{array}{l}95.0 \\
85.5 \\
79.2 \\
72.1 \\
68.1\end{array}$ & $\begin{array}{r}2.5 \\
10.3 \\
15.7 \\
21.5 \\
24.5\end{array}$ & $\begin{array}{l}2.5 \\
4.2 \\
5.1 \\
6.4 \\
7.4\end{array}$ & $\begin{array}{l}\text { (b) } \\
29.3^{24.5} \\
23.6 \\
23.1^{-1}\end{array}$ \\
\hline $\begin{array}{l}6 \ldots \ldots \\
7 \\
8 \\
9 \\
10\end{array}$ & $\begin{array}{l}47.4 \\
44.9 \\
49.0 \\
51.2 \\
33.5\end{array}$ & $\begin{array}{l}314 \\
314 \\
318 \\
319 \\
321\end{array}$ & $\begin{array}{l}70.7 \\
65.9 \\
57.1 \\
68.0 \\
52.3\end{array}$ & $\begin{array}{l}23.3 \\
27.0 \\
33.3 \\
23.1 \\
36.5\end{array}$ & $\begin{array}{r}6.0 \\
7.1 \\
9.6 \\
8.9 \\
11.2\end{array}$ & $\begin{array}{l}20.5 \\
22.1 \\
23.1 \\
27.7 \\
23.6\end{array}$ \\
\hline $\begin{array}{l}11 \ldots \\
12 \\
13 \\
14 \\
15\end{array}$ & $\begin{array}{l}50.3 \\
42.9 \\
28.7 \\
23.5 \\
43.2\end{array}$ & $\begin{array}{l}326 \\
326 \\
329 \\
329 \\
330\end{array}$ & $\begin{array}{l}43.5 \\
21.8 \\
26.3 \\
28.3 \\
18.8\end{array}$ & $\begin{array}{l}44.8 \\
63.8 \\
60.3 \\
60.0 \\
67.5\end{array}$ & $\begin{array}{l}11.7 \\
14.4 \\
13.4 \\
11.7 \\
13.7\end{array}$ & $\begin{array}{l}21.5 \\
18.5 \\
18.2 \\
16.4 \\
17.5\end{array}$ \\
\hline $\begin{array}{l}16 \\
17 \\
18 \\
19 \\
20 \ldots\end{array}$ & $\begin{array}{l}39.9 \\
27.6 \\
44.2 \\
43.8 \\
41.4\end{array}$ & $\begin{array}{l}331 \\
349 \\
352 \\
352 \\
367\end{array}$ & $\begin{array}{r}25.7 \\
5.8 \\
4.8 \\
4.7 \\
1.6\end{array}$ & $\begin{array}{l}60.4 \\
77.3 \\
78.1 \\
79.3 \\
80.5\end{array}$ & $\begin{array}{l}13.9 \\
16.9 \\
17.1 \\
16.0 \\
17.9\end{array}$ & $\begin{array}{l}18.8 \\
17.9 \\
18.0 \\
16.9 \\
18.2\end{array}$ \\
\hline & & & & & & $21.0 \pm 3.1$ \\
\hline
\end{tabular}

TABle 7. Pyrolytic fractionation of isoprene polymers-Con.

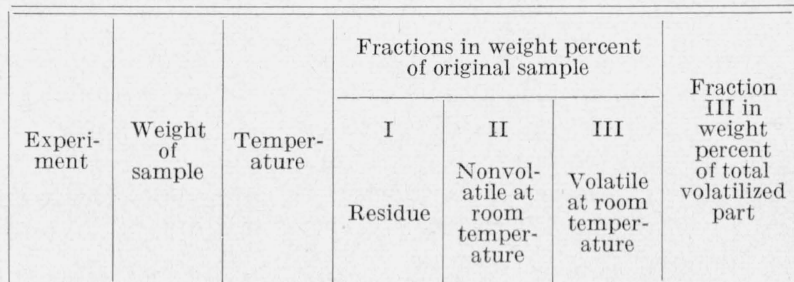

Gutta hydrocårbon (trans-polyisoprene)

\begin{tabular}{|c|c|c|c|c|c|c|}
\hline $\begin{array}{l}1 \\
2 \\
3 \\
4 \\
5\end{array}$ & $\begin{array}{l}47.3 \\
26.9 \\
38.8 \\
34.0 \\
48.6\end{array}$ & $\begin{array}{l}309 \\
316 \\
317 \\
317 \\
322\end{array}$ & $\begin{array}{l}90.6 \\
64.7 \\
63.5 \\
61.8 \\
65.0\end{array}$ & $\begin{array}{r}8.1 \\
26.9 \\
29.3 \\
30.1 \\
29.1\end{array}$ & $\begin{array}{l}1.3 \\
8.4 \\
7.2 \\
8.1 \\
5.9\end{array}$ & $\begin{array}{l}\text { (b) } \\
19.6 \\
20.7 \\
21.1 \\
22.7\end{array}$ \\
\hline $\begin{array}{l}6 \\
7 \\
8 \\
9 \\
10\end{array}$ & $\begin{array}{l}20.3 \\
26.1 \\
23.5 \\
38.8 \\
50.1\end{array}$ & $\begin{array}{l}329 \\
329 \\
354 \\
355 \\
357\end{array}$ & $\begin{array}{r}25.1 \\
21.5 \\
5.3 \\
8.6 \\
3.4\end{array}$ & $\begin{array}{l}62.9 \\
66.0 \\
78.0 \\
75.6 \\
79.2\end{array}$ & $\begin{array}{l}12.0 \\
12.5 \\
16.7 \\
15.8 \\
17.4\end{array}$ & $\begin{array}{l}16.0 \\
16.0 \\
17.2 \\
17.3 \\
18.0\end{array}$ \\
\hline $11 \ldots$ & 24.5 & 364 & 3.0 & 79.7 & 17.3 & 17. 6 \\
\hline
\end{tabular}

a This average is for experiments 5 to 11 , inclusive, where the residue was less than 32 percent.

b Too small to be accurately determined.

TABLE 8. Mass-spectrometer analysis of fraction IIIA obtained in the pyrolysis of synthetic polyisoprene

\begin{tabular}{|c|c|c|c|c|c|}
\hline \multirow{2}{*}{ Component } & \multicolumn{3}{|c|}{$\begin{array}{l}\text { Analysis of fraction IIIA } \\
\text { in experiments- }\end{array}$} & \multirow{2}{*}{$\begin{array}{c}\text { A verage } \\
\text { of exper- } \\
\text { iments } \\
3,6,9\end{array}$} & \multirow{2}{*}{$\begin{array}{c}\text { Average } \\
\text { for total } \\
\text { volatil- } \\
\text { ized } \\
\text { part }\end{array}$} \\
\hline & 3 & 6 & 9 & & \\
\hline $\begin{array}{l}\text { Isoprene } \\
\text { Pentenes }\end{array}$ & $\begin{array}{l}\text { Mole \% } \\
90.6 \\
3.8\end{array}$ & $\begin{array}{l}\text { Mole \% } \\
94.2 \\
2.2\end{array}$ & $\begin{array}{c}\text { Mole \% } \\
92.7 \\
5.4\end{array}$ & $\begin{array}{l}\text { Mole \% } \\
92.5 \\
3.8\end{array}$ & $\begin{array}{l}w t \% \\
3.2 \\
0.1\end{array}$ \\
\hline $\begin{array}{l}\text { Dipentene and its } \\
\text { isomers }\end{array}$ & Trace & Trace & Trace & Trace & Trace \\
\hline $\begin{array}{l}\text { Other hydrocar } \\
\text { bons }\end{array}$ & 5. 6 & & 1.9 & 3.7 & 0.1 \\
\hline Total & 100.0 & 100.0 & 100.0 & 100.0 & 3.4 \\
\hline
\end{tabular}

a Includes butenes, butane, hexadiene, and cyclohexadiene.

with small amounts of its isomers and with paramenthene, $\mathrm{C}_{10} \mathrm{H}_{18}$. Table 9 shows the relative amounts of monomer and dipentene in percentage of total volatilized part. As seen from this table, the amount of isoprene remains almost constant, whereas the amount of dipentene decreases with increasing temperature of degradation. 
TABLE 9. Distribution of monomer and dimer in fraction III obtained in the pyrolysis of synthetic polyisoprene

\begin{tabular}{|c|c|c|c|c|c|}
\hline \multirow{2}{*}{$\begin{array}{l}\text { Experi- } \\
\text { ment }\end{array}$} & \multirow{2}{*}{$\begin{array}{l}\text { Tempera- } \\
\text { ture }\end{array}$} & \multirow{2}{*}{$\begin{array}{c}\text { Total } \\
\text { volatilized } \\
\text { in weight } \\
\text { percent of } \\
\text { sample }\end{array}$} & $\begin{array}{c}\text { Total frac- } \\
\text { tion III }\end{array}$ & Monomer & Dimer \\
\hline & & & \multicolumn{3}{|c|}{ In weight percent of volatilized part } \\
\hline $\begin{array}{l}1 \\
2 \\
4 \\
70 \\
11\end{array}$ & $\begin{array}{l}{ }^{\circ} \mathrm{C} \\
309 \\
314 \\
320 \\
340 \\
369 \\
369\end{array}$ & $\begin{array}{l}w t \% \\
21.3 \\
26.8 \\
44.3 \\
76.6 \\
95.7 \\
95.1\end{array}$ & $\begin{array}{l}w t \% \\
18.1 \\
16.8 \\
16.1 \\
12.9 \\
12.0 \\
11.6\end{array}$ & $\begin{array}{c}w t \% \\
3.4 \\
3.1 \\
3.3 \\
3.2 \\
3.7 \\
3.5\end{array}$ & $\begin{array}{r}\text { wt } \% \\
14.7 \\
13.7 \\
12.8 \\
9.7 \\
8.3 \\
8.1\end{array}$ \\
\hline
\end{tabular}

The average molecular weight of fraction II from polyisoprene has been reported in a previous publication [2]. It was determined in a solution of cyclohexane and was found to be 577. Mass-spectrometer analysis of fraction IV has also been reported previously. This fraction was found to consist of methane.

\subsection{Natural Rubber (cis-Polyisoprene)}

Pale crepe rubber ${ }^{5}$<smiles>C/C=C\C</smiles>

was extracted for $96 \mathrm{hr}$ in a Soxhlet apparatus in an atmosphere of $\mathrm{CO}_{2}$ and washed with benzene. This treatment removes most of the resinous material but not the protein. The solvents were evaporated at $60^{\circ}$ to $70^{\circ} \mathrm{C}$. The results of 20 pyrolysis experiments are shown in table 7 . Here, as in isoprene, the relative amount of fraction III is higher in the early stages of degradation. On the average, fraction III amounts to $21.0 \pm 3.1$ percent of the total volatilized part.

Fraction III was separated at $-80^{\circ} \mathrm{C}$ by $30-\mathrm{min}$ fractionation into IIIA and IIIB. Results of massspectrometer analysis of fraction IIIA are shown in table 10. Fraction IIIB was also analyzed in the

TABLE 10. Mass-spectrometer analysis of fraction IIIA obtained in the pyrolysis of natural rubber (cis-polyisoprene)

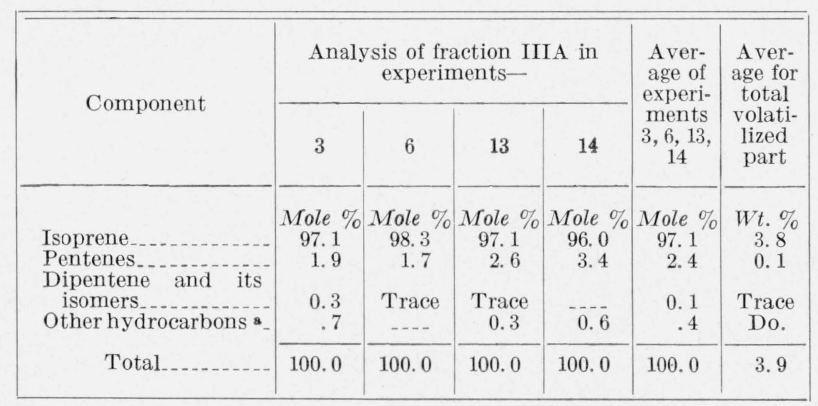

a Includes butenes, butane, hexadiene, and cyclohexadiene.

5 Purification of cis-rubber, as well as of trans-rubber, was carried out Iby Tryon of the Rubber Section of the National Bureau of Standards.
TABLE 11.-Distribution of monomer and dimer in fraction III obtained in the pyrolysis of natural rubber (cis-polyisoprene)

\begin{tabular}{|c|c|c|c|c|c|}
\hline \multirow[t]{2}{*}{ Experiment } & \multirow{2}{*}{$\begin{array}{l}\text { Tempera- } \\
\text { ture }\end{array}$} & \multirow{2}{*}{$\begin{array}{l}\text { Total vola- } \\
\text { tilized in } \\
\text { weight per- } \\
\text { cent of } \\
\text { sample }\end{array}$} & $\begin{array}{c}\text { Total frac- } \\
\text { tion III }\end{array}$ & Monomer & Dimer \\
\hline & & & \multicolumn{3}{|c|}{ In weight percent of volatilized part } \\
\hline $\begin{array}{l}4 \\
7 \\
8 \\
11 \\
15 \\
19\end{array}$ & $\begin{array}{l}{ }^{\circ} C \\
311 \\
314 \\
318 \\
326 \\
330 \\
352\end{array}$ & $\begin{array}{l}W t \% \\
27.9 \\
34.1 \\
42.9 \\
56.5 \\
81.2 \\
95.3\end{array}$ & $\begin{array}{l}W t \% \\
23.6 \\
22.1 \\
23.1 \\
21.5 \\
17.5 \\
16.9\end{array}$ & $\begin{array}{l}W t \% \\
\quad 4.1 \\
3.9 \\
4.1 \\
3.8 \\
3.8 \\
3.9\end{array}$ & $\begin{array}{l}W t \% \\
19.5 \\
18.2 \\
19.0 \\
17.7 \\
13.7 \\
13.0\end{array}$ \\
\hline
\end{tabular}

mass spectrometer and was found to contain mostly dipentene, mixed with a small amount of its isomers and with $p$-menthene. Table 11 shows relative amounts of isoprene and dipentene in percentage of total volatilized part. Here again the amount of isoprene is independent of temperature of pyrolysis, while the amount of dipentene decreases with increase of temperature. However, on the whole, the dipentene content is higher in the case of cis-polyisoprene than it is in the case of synthetic polyisoprene.

The wax-like fraction II was not soluble in cyclohexane and insufficiently soluble in benzene for cyroscopic molecular-weight determinations. These determinations were therefore carried out in a solution in camphor. The average of three determinations was 616 , as shown in table 3 . Fraction IV was very small and consisted of $\mathrm{CO}, \mathrm{CO}_{2}$, and air. The residue was slightly soluble in cold benzene.

\subsection{Gutta Hydrocarbon (trans-polyisoprene)}

Gutta hydrocarbon<smiles>CC=CC</smiles>

or trans-polyisoprene was purified in the same manner as cis-polyisoprene. Results of 11 pyrolysis experiments are shown in table 7 . Fraction III comprised, on the average, $18.6 \pm 1.9$ percent of the total pyrolyzed part. Fraction III was separated into IIIA and IIIB during $30 \mathrm{~min}$ at $-80^{\circ} \mathrm{C}$. Massspectrometer analysis of IIIA is shown in table 12 , and relative amounts of isoprene and dipentene are shown in table 13 . In respect to isoprene-dipentene ratios, trans-polyisoprene resembles more closely cis-polyisoprene than synthetic polyisoprene. Fraction IIIB contained mainly dipentene, mixed with small amounts of its isomers and para-menthene.

Fraction II was soluble in benzene, and its molecular weight was determined in this solvent. The average of four determinations was 554, as shown in table 3. Fraction IV here again was very small and contained $\mathrm{CO}, \mathrm{CO}_{2}$, and air. The residue was soluble in cold benzene. 
TABLE 12. Mass-spectrometer analysis of fraction IIIA obtained in the pyrolysis of gutta hydrocarbon (trans-polyisoprene)

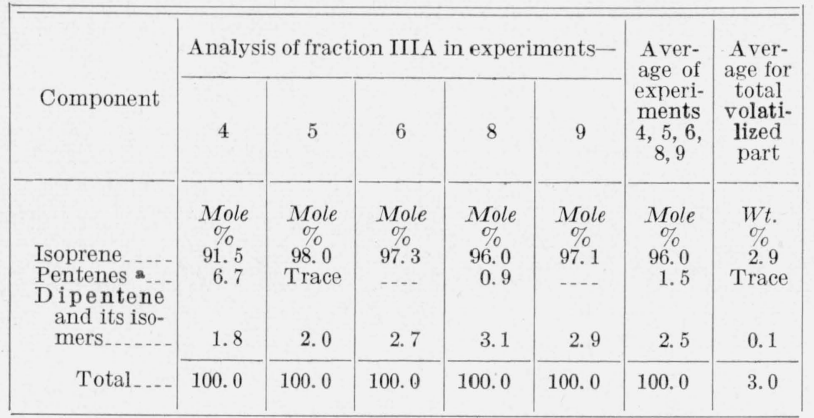

a Includes also small amounts of other $\mathrm{C}_{5}$ and of $\mathrm{C}_{6}$ hydrocarbons.

TABLE 13. Distribution of monomer and dimer in fraction III obtained in the pyrolysis of gutta hydrocarbon (trans-polyisoprene)

\begin{tabular}{|c|c|c|c|c|c|}
\hline \multirow[t]{2}{*}{ Experiment } & \multirow{2}{*}{$\begin{array}{l}\text { Tempera- } \\
\text { ture }\end{array}$} & \multirow{2}{*}{$\begin{array}{c}\text { Total } \\
\text { volatilized } \\
\text { in weight } \\
\text { percent of } \\
\text { sample }\end{array}$} & $\begin{array}{l}\text { Total frac- } \\
\text { tion III }\end{array}$ & Monomer & Dimer \\
\hline & & & \multicolumn{3}{|c|}{ In weight percent of volartilized part } \\
\hline $\begin{array}{l}2 \ldots \ldots \ldots \\
3 \\
7 \\
11\end{array}$ & $\begin{array}{l}{ }^{\circ} C \\
316 \\
317 \\
329 \\
364\end{array}$ & $\begin{array}{l}w t \% \\
35.3 \\
36.5 \\
78.5 \\
97.0\end{array}$ & $\begin{array}{l}\text { wt } \% \\
19.6 \\
20.7 \\
16.0 \\
17.6\end{array}$ & $\begin{array}{l}\text { wt } \% \\
3.0 \\
3.0 \\
2.9 \\
3.2\end{array}$ & $\begin{array}{l}\text { wt \% } \\
16.6 \\
17.7 \\
13.1 \\
14.4\end{array}$ \\
\hline
\end{tabular}

\section{Discussion of Results}

In the styrene group of polymers, poly-alphadeuterostyrene and poly-meta-methylstyrene resemble polystyrene [1] in their pattern of thermal degradation. All three polymers yield a considerable amount of monomer and a fraction II, which has an average molecular weight about one-half as large as in the case of other polymers investigated (table 3). This low molecular weight of fraction II can be accounted for only by assuming that it consists of a mixture of dimer, trimer, and some tetramer [11]. Poly-alpha-methylstyrene, on the other hand, resembles polymethyl methacrylate in yielding almost 100 percent of monomer.

A summary of monomer fraction yield for all polymers of this investigation, and for polyethylene, polyisobutene, polystyrene, and polybutadiene, in a previous investigation $[1,2]$, is given in table 14 . In the second column of this table the yield is expressed in weight percent and in the third column, in mole percent of the volatilized part.

In the case of polymethyl methacrylate, the benzoyl peroxide catalyzed polymer A, molecular weight 150,000 , yielded on pyrolysis 96 weight percent of monomer and 4 weight percent of nonmonomer-size molecules. The thermally prepared polymer B, molecular weight 5,100,000, yielded almost 100 percent of monomer. However, the more surprising difference in the behavior of these two polymers is the fact that polymer $\mathrm{A}$ pyrolyzed at temperatures of about $50^{\circ}$ to $60^{\circ} \mathrm{C}$ lower than polymer $\mathrm{B}$ (see
TABLE 14. Amount of monomeric fraction obtained in the pyrolysis of polymers

\begin{tabular}{|c|c|c|}
\hline \multirow[t]{2}{*}{ Polymer } & \multicolumn{2}{|c|}{$\begin{array}{l}\text { Monomeric fraction } \\
\text { in percentage of } \\
\text { volatilized part }\end{array}$} \\
\hline & $W t \%$ & Mole \% \\
\hline Polyethylene. & 3 & 21 \\
\hline Hydrogenated polystyrene. & 6 & 25 \\
\hline Polyisobutene & 32 & 78 \\
\hline Polystyrene. & 42 & 65 \\
\hline Poly-meta-methylstyrene. & 52 & 77 \\
\hline Poly-alpha-deuterostyrene. & 70 & 86 \\
\hline Poly-alpha-methylstyrene... & 100 & 100 \\
\hline Polymethyl acrylate s & 27 & \\
\hline Polymethyl methacrylate $A \ldots \ldots \ldots \ldots \ldots \ldots$ & 96 & 99 \\
\hline Polymethyl methacrylate $\mathrm{B}$ & 100 & 100 \\
\hline Polybutadiene. & 14 & 57 \\
\hline Synthetic polyisoprene & 12 & 42 \\
\hline trans-Polyisoprene & 19 & 55 \\
\hline cis-Polyisoprene... & 21 & 59 \\
\hline
\end{tabular}

s In view of the fact that fraction III from this polymer contained a large amount of $\mathrm{CO}_{2}$ and $\mathrm{MeOH}$, the mole percent of the monomeric fraction could not be calculated.

table 5, also fig. 1). As was pointed out in another paper [11], this difference is due mainly to the different methods by which the polymers were prepared and not to the differences in their molecular weights.

In hydrogenated polystyrene the conditions approach those of polyethylene. The yield of monomeric molecules is small, and its amount is constant in percentage of total volatilized part (table 1); also, fraction II has a high molecular weight.

Polymethyl acrylate resembles the other vinyl polymers in one respect, that the amount of fraction III (table 5) is independent of temperature or extent of volatilization. In respect to composition of this fraction, however, this polymer differs radically from the other polymers. Fraction III from methyl acrylate pyrolysis consists mainly of $\mathrm{CO}_{2}$ and $\mathrm{CH}_{3} \mathrm{OH}$, which are fragments of the carboxylic side groups. The monomer appears to the extent of only a few percent.

In the isoprene group of polymers, the pattern of breakup is almost the same for the three polymers. The differences appear in the amount of fraction III, this being 12,19 , and 21 weight percent, or 42,55 , and 59 mole percent, of total volatilized part in synthetic polyisoprene, trans-polyisoprene, and cispolyisoprene, respectively. The vield of isoprene is about the same in all three polymers, so that the differences in fraction III are due to differences in the yield of dipentene. On the basis of tables 9, 11, and 13 , the average weight ratios of dipentene to isoprene are: for synthetic polyisoprene, from 4.3:1 at $309^{\circ} \mathrm{C}$ to $2.3: 1$ at $369^{\circ} \mathrm{C}$; for cis-polyisoprene, from $4.8: 1$ at $311^{\circ} \mathrm{C}$ to $3.3: 1$ at $352^{\circ} \mathrm{C}$; for transpolyisoprene, from $5.5: 1$ at $316^{\circ} \mathrm{C}$ to $4.5: 1$ at $364^{\circ} \mathrm{C}$. On the whole, there is a close resemblance in the behavior of the three isoprene polymers during thermal degradation. However, there is a closer resemblance between the two natural rubbers in regard to the amount of dipentene formed.

A comparison of thermal stability of 10 polymers studied in this paper and of 4 polymers and 1 copolymer studied previously $[1,2]$ is shown in figures 1 
and 2. The curves are based on experiments carried out under similar conditions. The curves for polyisoprene polymers are shown separately in figure 2 because they would appear too crowded if included in figure $1 .^{6}$

Fraction III or IIIA obtained in the pyrolysis of polymers gives on mass-spectrometer analysis a characteristic spectrum. The spectra of these fractions, including the spectrum of a sample of pure dipentene, are shown in figures 3 and 4 . In these figures the abscissas are mass numbers, and the ordinates are on a scale of 100 for the maximum peak. Mass spectra like these could serve as a basis for the identification of polymers.

The authors express their indebtedness to F. L. Mohler for many helpful suggestions, to L. Wall for the preparation of some of the polymers, to R. M. Reese and E. Quinn, respectively, for the operation

${ }^{6}$ Curves for the polymers studied previously are shown in figure 2 of [2]. How ever, because of an error, all the temperatures are reported $25 \mathrm{deg} \mathrm{C}$ too high. This error has been corrected in figures 1 and 2 of the present work. of the mass spectrometer and analysis of the mass spectra, and to M. Tryon, who purified some of the polymers used in this work.

\section{References}

[1] S. L. Madorsky and S. Straus, J. Research NBS 40, 417 (1948) RP1886; Ind. Eng. Chem. 40, 484 (1948).

[2] S. L. Madorsky, S. Straus, D. Thompson, and L. Williamson, J. Research NBS 42, 499 (1949) RP1989; J. Polymer Sci. 4, 639 (1949).

[3] R. Simha, L. A. Wall, and P. J. Blatz, J. Polymer Sci. 5, 615 (1950).

[4] R. Simha and L. A. Wall, J. Phys. Chem. 56, 707 (1952).

[5] Leo A. Wall, J. Research NBS 41, 315 (1948).

[6] H. H. G. Jellinek, J. Polymer Sci. 4, 13 (1949).

[7] N. Grassie and H. W. Melville, Proc. Royal Soc. (London) 199, 1 (1949).

[8] R. L. Shriner and R. C. Fuson, Identification of organic compounds (John Wiley \& Sons, Inc., New York, N. Y., 1940).

[9] G. Gee, Trans. Faraday Soc. 36, 1162 (1940).

[10] D. J. Brawley and S. G. Weissberg, unpublished work.

[11] S. L. Madorsky, J. Polymer Sci. (In press). (1953).

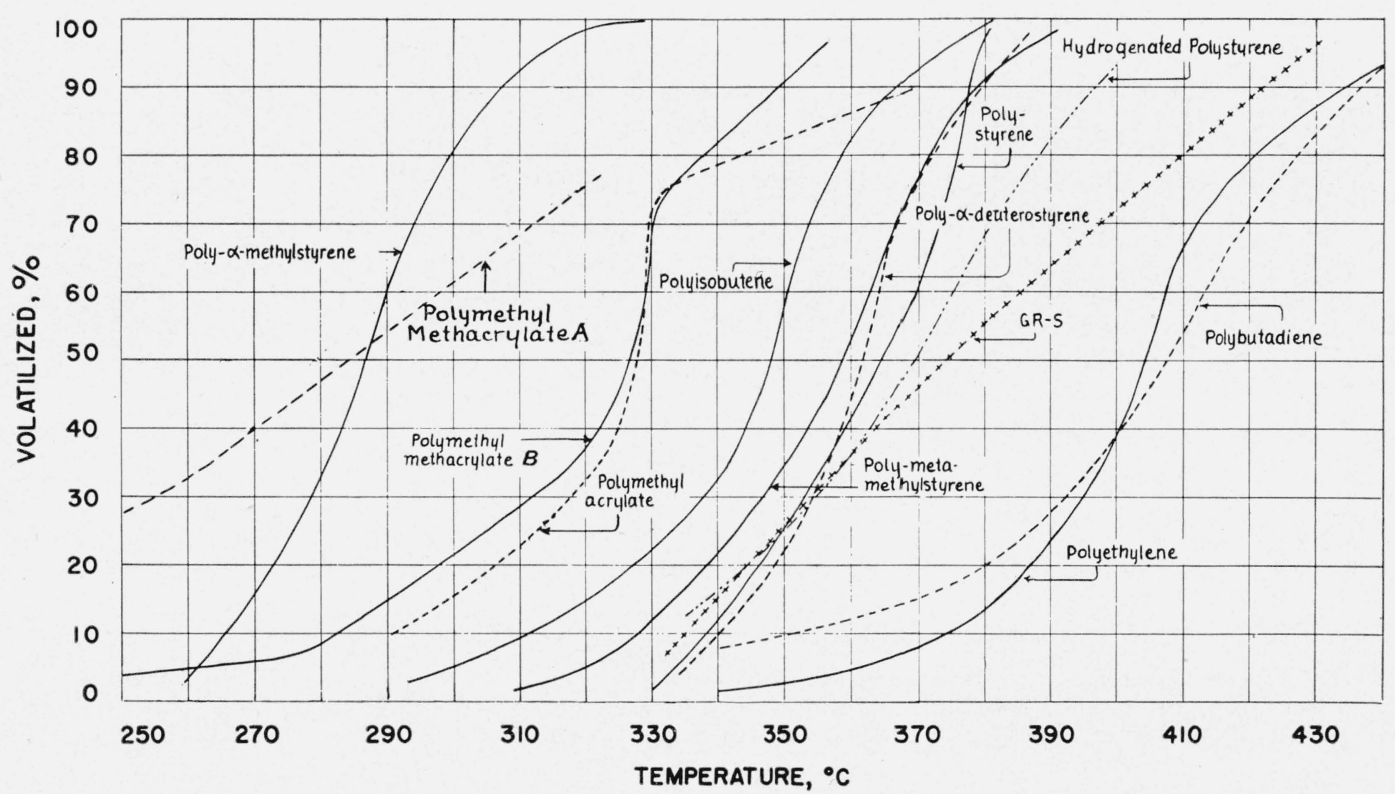

Figure 1. Relative thermal stability of vinyl and diene polymers. 
FIGURE 2. Relative thermal stability of synthetic polyisoprene. natural rubber (cis-polyisoprene), and guttahydrocarbon (trans-polyisoprene).
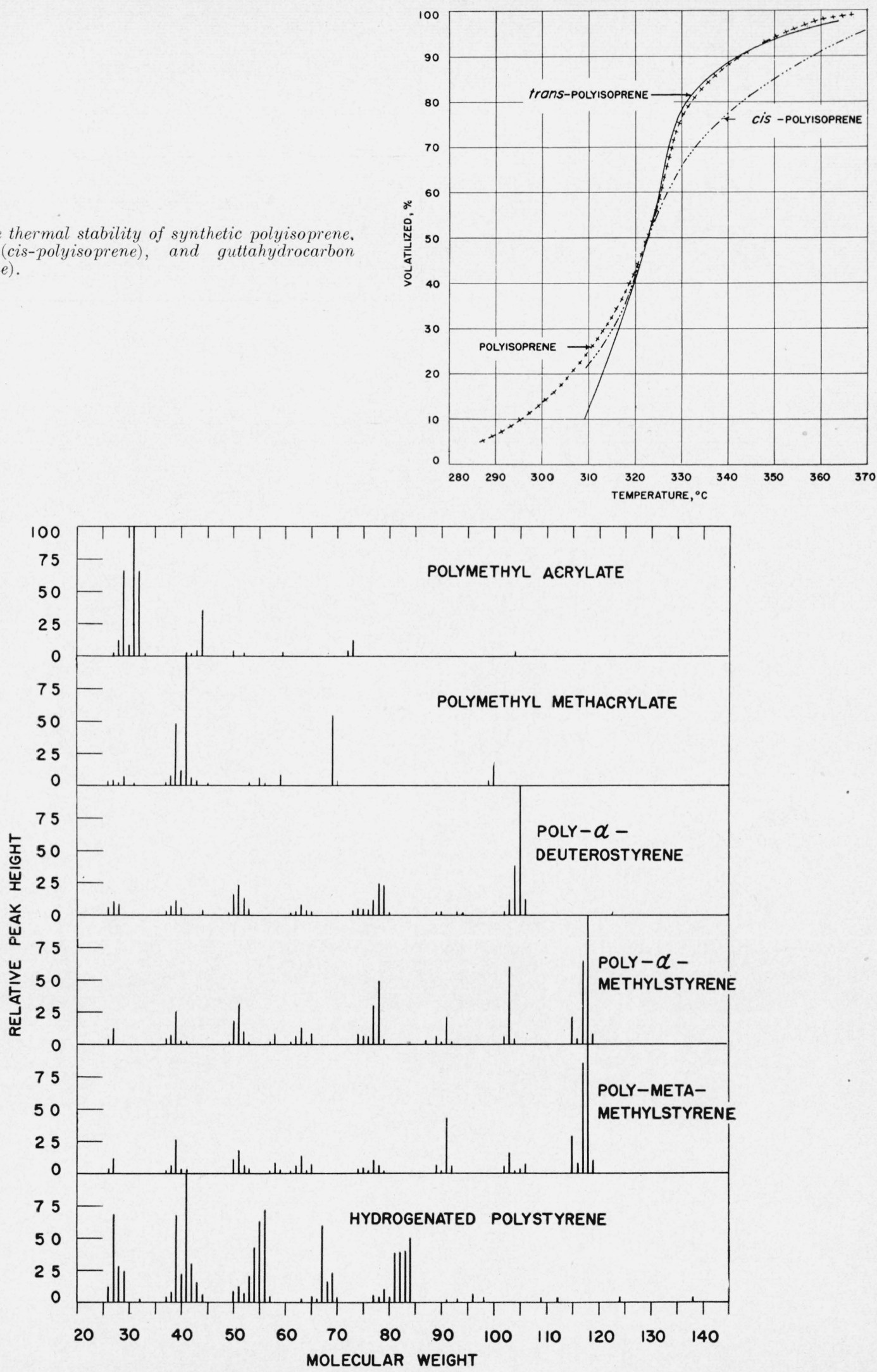

FIGURE 3. Mass spectra of fraction III obtained in the pyrolysis of polymers. 


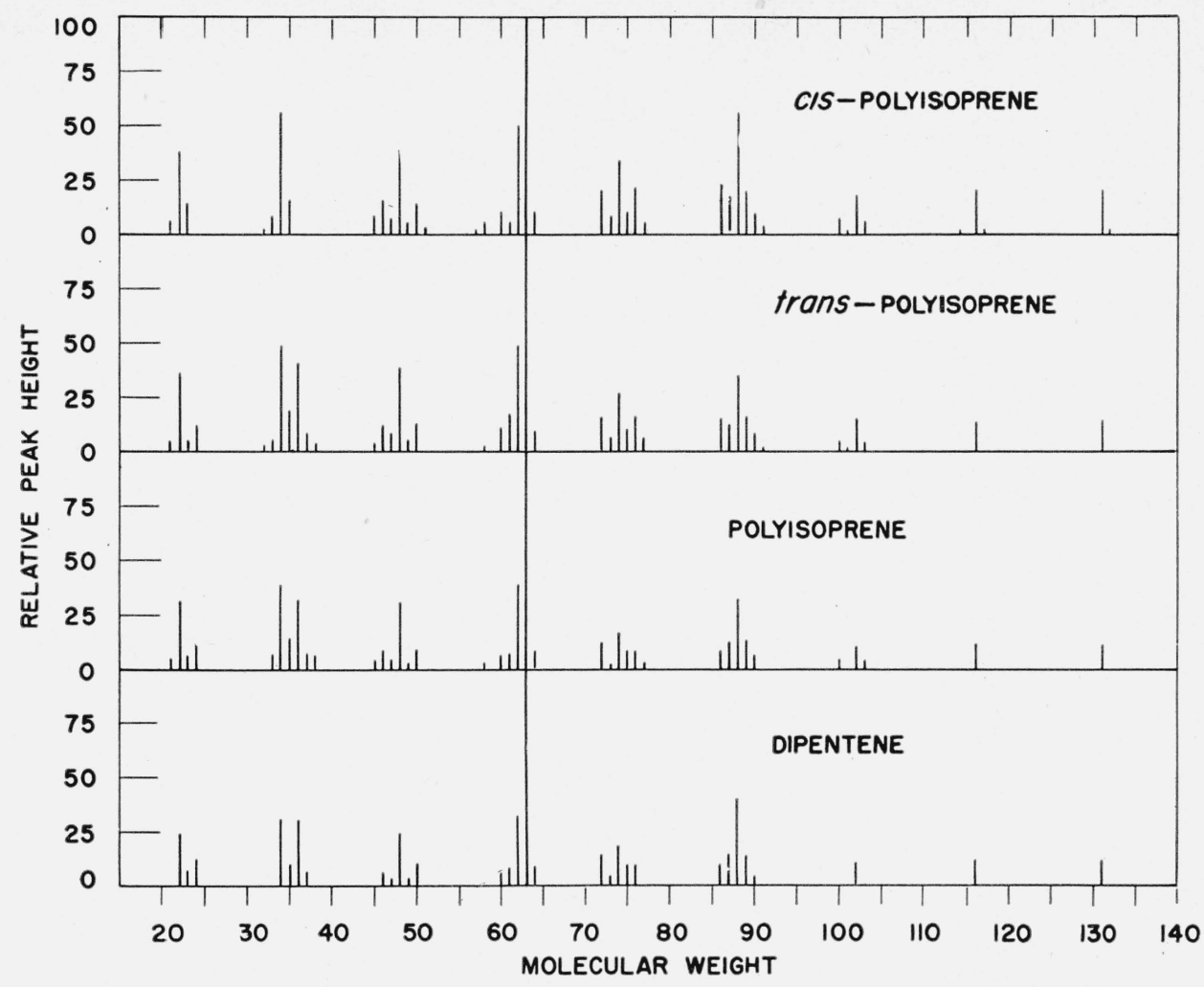

FIGURE 4. Mass spectra of fraction III obtained in the pyrolysis of synthetic polyisoprene, natural rubber (cis-polyisoprene, guttahydrocarbon (trans-polyisoprene), and dipentene.

Washington, June 16, 1952. 